\title{
PELATIHAN DAN PEMBINAAN HEALTH AND HYGIENE EDUCATION (HHE) BAGI PENGGUNA SANIMAS DI KOTA KEDIRI
}

\author{
*Indasah, Intan Fazrin, Ridha Rachmathiany \\ STIKES Surya Mitra Husada Kediri \\ Email : iin.dasyah@yahoo.com
}

\begin{abstract}
ABSTRAK
Kegiatan Pengabdian untuk pelatihan, pembinaan pada kelompok swadaya masyarakat "KSM" SANIMAS (sanitasi Berbasis Masyarakat) di Kota Kediri . Kegiatan ini bertujuan untuk: meningkatkan kesadaran tentang permasalahan kesehatan dan hygiene dengan menyediakan informasi yang tepat dan mempromosikan praktek kesehatan dan hygiene yang baik. Kegiatan ini dilakukan dengan metode focus grup discussion (FGD) sehingga partisipan dapat mengemukakan permasalahan dan mendapatkan solusi yang tepat. Hasil kegiatan ini partisipan mendapat informasi tentang sanimas dan health hygiene education (HHE) yang dapat memberdayakan masyarakat untuk mencegah penyakit terkait sanitasi, memperbaiki perilaku kesehatan dan hygiene, mencegah penyakit diare dengan memutus rute kontaminasi, memberikan pengetahuan yang tepat mengenai perawatan fasilitas sanitasi dan inovasi dari pengolahan limbah seperti halnya dalam pembuatan biogas, program hidroponik, budidaya ikan, tempat mandi cuci kakus yang indah untuk sarana edukasi serta pemahaman dan keterampilan organisasi dan perawatan SANIMAS. Dukungan kerjasama pemerintah kota, lintas sektor dan masyarakat sehingga mewujudkan kota Kediri bebas dari buang air besar sembarangan, lingkungan yang sehat, bersih, indah, dan bermanfaat.
\end{abstract}

Kata Kunci : Pelatihan, Pembinaan, Sanitasi, Pengetahuan, Motivasi 


\begin{abstract}
The activities of community service for coaching of community self help group "KSM"SANIMAS (Society Based Sanitation)in Kediri City. This activities aim to increase aworeness about health and hygiene problems by providing accurately information and promoting good health and hygiene pratices. The activities are used focus group discussion (FGD) method so the participants can tell the problems and get good solution. The result of these activities, the participants get the infomation about SANIMAS and health hygiene education (HHE) which can empower society to prevent the disease related to sanitation, improve health and hygiene behavior, prevent diarrheal disease by breaking contamination route, giving appropriate knowledge about caring sanitation facilities and inovation from waste management such as making biogas, hydroponic program, fish cultivation, beatiful toilet for education also understanding and organizational skills and care SANIMAS. Collaborative support from city goverment, cross sector and society,so that it creates Kediri city free from defecate carelessly, healthy, clean, beatiful and useful enviroment.
\end{abstract}

Keywords: Training, Coaching, Sanitation, Knowledge, Motivation

\title{
PENDAHULUAN
}

Pengelolaan air limbah di Kota Kediri belum sepenuhnya berjalan optimal. Terlihat dengan masih banyak masyarakat yang melakukan praktek BAB sembarangan (BABs). Beberapa inisiatif telah dilakukan oleh Pemerintah Kota Kediri, antara lain dengan pembangunan IPAL Komunal berbasis masyarakat (Sanimas) di beberapa wilayah padat penduduk dan kumuh di Kota Kediri .SANIMAS merupakan suatu program yang tujuannya untuk meningkatkan kualitas lingkungan. Kegiatan dari program SANIMAS ini adalah pembangunan sarana dan prasarana air limbah pemukiman serta berkelompok. Oleh karena penggunaannya berkelompok, maka perlu kelembagaan untuk pengelolaannya.

Sasaran dari program ini adalah kesehatan, yaitu kesehatan lingkungan yang memberikan dampak langsung kepada masyarakat. Menurut pengabdian kepada masyarakat yang telah dilakukan (oleh LSM), penduduk yang mengalami sakit akibat pencemaran air limbah lebih banyak jumlahnya daripada penduduk yang tidak sakit. Dengan adanya sarana sanitasi yang terkelola dengan baik, maka hal-hal positif yang terjadi antara lain adalah :

a. Penurunan angka kematian bayi

b. Umur harapan hidup meningkat 
c. Angka diare menjadi turun

d. Peningkatan kapasitas SDM untuk pelayanan kesehatan (dokter, perawat, puskesmas)

e. Peningkatan jumlah sarana kesehatan

Akan tetapi fasilitas sanitasi saja tidak cukup untuk meningkatkan taraf hidup dan menjaga kesehatan penduduk yang tinggal dikawasan perkotaan yang merupakan target utama program Sanitasi Berbasis Masyarakat. Meningkatkan kesehatn dan hygiene di lingkungan masyarakat secara berkelanjutan harus sejalan dengan mencegah timbulnya meningkatkan pengetahuan dan kesadran akan pencegahan penyakit disamping menyediakan sarana fisik. Oleh Karena itu kita harus memberikan akses informasi yang tepat pada kelompok sasran mengenai hygiene yang baik untuk mencegah timbulnya penyakit terkait sanitasi.

Pendidikan Kesehatan dan Hygiene (HHE) untuk program CBS-DEWATS merupakan pendekatan yang dikembangkan untuk mempromosikan perilaku hygiene yang benar dan memberikan pemahaman kepada orang dewasa dan juga anak-anak yang tinggal di kawasan dengan hygiene individual dan pencegahan penyakit. HHE (Pendidikan Kesehatan dan Hygiene) menggunakan metode focus grup discussion (FGD) dengan menggali pengetahuan masyarakat sekaligus menggunakan kemampuan yang mereka miliki untuk menyelasaikan permasalahan sanitasi yang ada. Hal ini bertujuan untuk memberdayakan masyarakat agar dapat mencegah penyakit terkait sanitasi dengan mempromosikan kesadaran dan pengetahuan akan kesehatan yang benar, yang dapat meningkatkan kondisi kesehatan dan juga lingkungan.

Focus dari ini adalah untuk memberikan informasi dan melatih masyarakat mengunakan SANIMAS tentang rute kontaminasi dari penyakit terkait sanitasi dan cara-cara untuk memutus rute kontaminasi tersebut. Selain itu, dengan ini diharapkan agar dapat memberikan informasi kepada masyarakat tentang bahaya buang air besar sembarangan serta merubah perilaku kesehatan danhygiene dari yang tidak baik menjadi baik.

Secara Umum permasalahan yang dihadapi dan harus dipecahkan KSM Kota Kota Kediri dilihat dari berbagai sudut pandang yang relevan. 
1. Permasalahan pertama adalah kendala biaya pemeliharaan akibat pengelolaan yang belum optimal

2. Permasalahan kedua adalah menata sistem manajemen yang selama ini dilakukan secara sederhana menjadi manajemen yang profesional.

3. .Permasalahan ketiga Belum memiliki perencanaan pengelolaan yang jelas sehingga belum memiliki arah pengembangan pengelolaan yang lebih mapan.

4. Permasalahan keempat Manajemen keuangan yang belum memenuhi standar akuntansi. belum ada manajemen pembiayaan yang baik..

5. Permasalahan kelima Masih kurangnya motivasi pengelolaan.

6. Permasalahan keenam, masih rendahnya PHBS di kalangan pengguna Sanimas

7. Permasalahan ketujuh : rendahnya kesadaran masyarakat tentang permasalahan kesehatan dan hygiene

Berdasarkan berbagai permasalahan tersebut maka tujuan dari pelaksanaan pengabdian pada KSM Balowerti secara umum adalah mengembangkan pengelolaan sanimas yang mampu menyediakan berbagai sarana seperti pelatihan atau pendidikan HHE, serta dikelola secara profesional sehingga seluruh masyarakat mampu berpartisipasi dalam pengelolaan sanimas.

Secara khusus tujuan Pengabdian yang akan dilaksanakan adalah:

1.Meningkatkan pengetahuan dan ketrampilan pengelolaan sehingga kendala biaya bisa diselesaiakan.

2, Meningkatkan pengetahuan dan ketrampilan dalam Menata sistem manajemen yang selama ini dilakukan secara sederhana menjadi manajemen yang profesional.

3, Meningkatkan pengetahuan dan ketrampilan dalam melaksanakan perencanaan pengelolaan yang jelas sehinggamemiliki arah pengembangan pengelolaan yang lebih mapan.

4. Meningkatkan pengetahuan dan ketrampilan dalam memperbaiki Manajemen keuangan sesuai standar akuntansi. Dan ada manajemen pembiayaan yang baik..

5.Meningkatkan motivasi pengelolaan.

6.Meningkatkan pengetahuan dan ketrampilan PHBS di kalangan pengguna Sanimas. 
7,Meningkatkan kesadaran tentang permasalahan kesehatan dan hygiene dengan menyediakan informasi yang tepat dan mempromosikan praktek kesehatan dan hygiene yang baik.

a. Memberdayakan masyarakat untuk mencegah penyakit terkait sanitasi

b. Memperbaiki perilaku kesehatan dan hygiene

c. Mencegah penyakit diare dengan memutus rute kontaminasi

d. Memberikan pengetahuan yang tepat mengenai perawatan fasilitas sanita

\section{METODE PELAKSANAAN}

Melalui kegiatan Pengabdian ini akan ditawarkan solusi bagi permasalahanpermasalahan yang telah dirumuskan di atas. Pendekatan yang ditawarkan bagi realisasi program Pengabdian ini adalah model pemberdayaan dengan langkah-langkah sebagai berikut : 1) Tahap Persiapan; 2) Tahap Assesment; 3) Tahap Perencanaan Alternatif Program atau Kegiatan; 4) Tahap Pemformulasian Rencana Aksi; 5) Tahap Pelaksanaan (Implementasi) Program atau Kegiatan; 6) Tahap Evaluasi; serta 7) Tahap Terminasi.

Pelaksanaan program Pengabdian ini memang dilaksanakan sebagai upaya pemberdayaan kelompok masyarakat melalui kegiatan pelatihan managemen yang menitikberatkan kepada pengembangan upaya pengelolaan SANIMAS. Metode pelaksanaan program yang akan dilakukan adalah : (1) pelatihan manajemen pembiayaan , (2) Pelatihan managemen organisasi, (3) pelatihan managemen perencanaan (4) Pelatihan managemen keuangan (5) Pelatihan pemberian motivasi (6) Pelatihan PHBS (7) Health and Hygiene Education (HHE) Semua metode ini merupakan satu kesatuan dari program Pengabdian ini.HHE (Pendidikan Kesehatan dan Hygiene) menggunakan metode Kegiatan ini adalah memberikan pelatihan dan pembinaan dengan metode focus group disccusiom (FGD ). Pengalaman dari pelaksana program adalah staf pengajar Kesehatan Lingkungan yang kompeten untuk pengembangan pengelolaan SANIMAS. Tim terdiri dari 2 orang yang berpengalaman dalam Pengabdian. Tim pengusul memiliki kewenangan dan kompetensi bidang Kesehatan Lingkungan. Sementara itu pakar sebagai narasumber materi pelatihan juga memiliki kompetensi di bidang kesehatan lingkungan sehingga tim mengusulkan tenaga ahli dari program kesehatan lingkungan dan praktisi. 
Program kegiatan pelatihan ini akan berhasil jika semua pihak yang terkait mendukung dan mau bekerjasama dengan baik. Adapun pihak yang mendukung:

a. Tim pelaksana kegiatan pengabdian kepada masyarakat yang mempunyai keahlian di bidang managemen pembiayaan, managemen organisasi, managemen keuamham HHE.

Tim mahasiswa dipilih yang telah belajar kesehatan lingkungan sehingga mampu mendukung dalam proses pelatihan pengelolaan SANIMAS, serta bermanfaat sebagai sarana belajar secara nyata dimasyarakat.

b. Perangkat Kelurahan setempat, yaitu pejabat Kelurahan se kota kediri , KSM yang berkompeten untuk memberikan dukungan dan motivasi kepada anggota kelompok lain.

c. Perwakilan Dinas Kesehatan Kota Kediri,dukungan pemerintah dibutuhkan oleh mitra usaha untuk mengawasi kelancaran jalannya program dan keberlanjutan program. sehingga akan mendukung keberhasilan wilayah dalam membantu mengatasi pengelolaan limbah rumah tangga terutama black water..

d. AKSANSI adalah Asosiasi KSM Sanitasi Seluruh Indonesia, sebuah asosiasi yang beranggotakan KSM (Kelompok Swadaya Masyarakat) Sanitasi, sebagai wadah atau forum komunikasi bagi para pengurus KSM dan operator Sanitasi yang tersebar hampir di seluruh Indonesia, yang selama ini telah menjalin kerjasama dengan tim serta mampu menyediakan informasi dan penyediaan pelatihan managemen SANIMAS untuk pengelolaan SANIMAS yang digunakan ketika melaksanakan program pengabdian 


\section{HASIL DAN PEMBAHASAN}

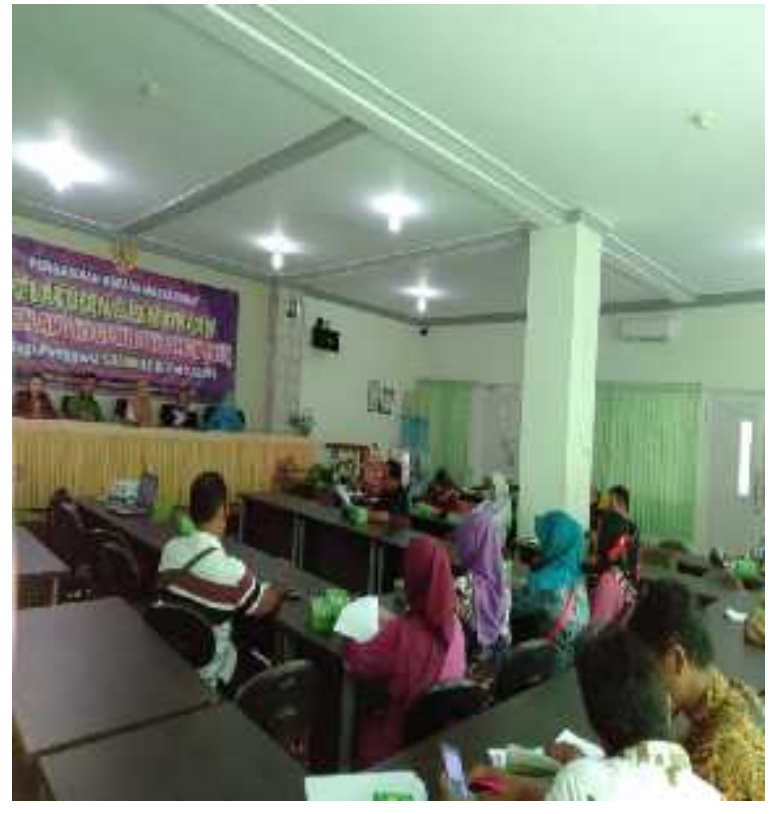

Gambar 4.2.1 Kegiatan mengisi Kuesioner

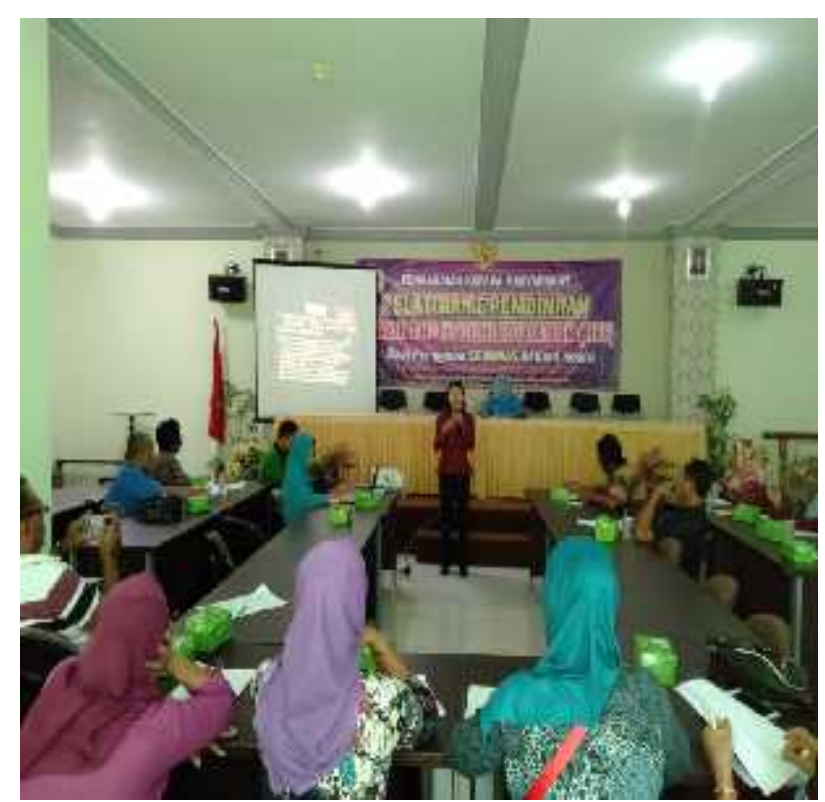

Gambar 4.2.2 Kegiatan pelatihan dan pembinaan oleh narasumber dari Dinas Kesehatan bidang kesehatan lingkungan

Kegiatan pelatihan dan pembinaan oleh narasumber dari Dinas Kesehatan bidang kesehatan lingkungan dan koordinator SANIMAS memnggunakan dengan metode FGD (Focus Group Discussion) yaitu merupakan suatu tehnik digunakan untuk menyelesaikan suatu masalah dengan berdiskusi dengan waktu yang singkat sehingga dapat meningkatkan pengetahuan, menyamakan persepsi, memberikan motivasi, ada perubahan perillaku antara narasumber, partisipan dan moderator (Indrizal, 2014). 


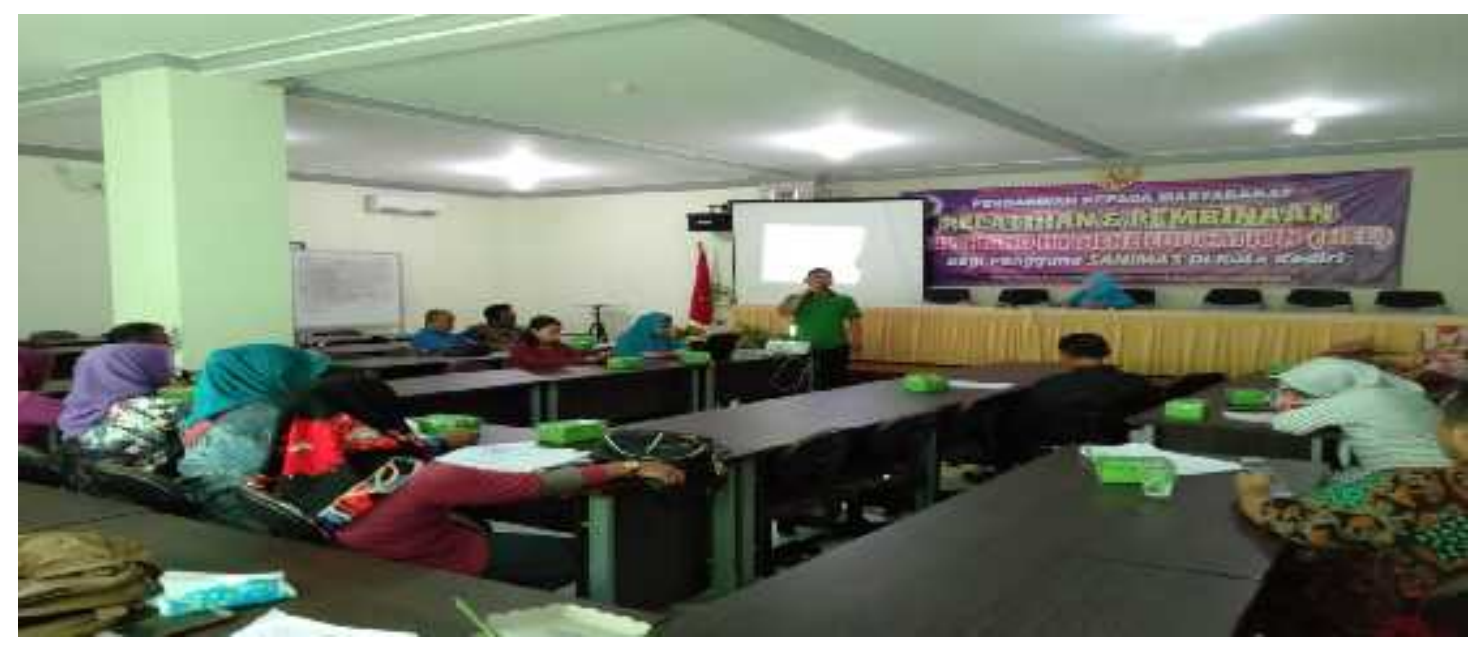

\section{Gambar 4.2.2 Kegiatan pelatihan dan pembinaan oleh narasumber dari Koordinatos SANIMAS Kota Kediri}

Pelatihan dan pembinaan SANIMAS tersebut tentang pengetahuan perilaku hidup bersih dan sehat (PHBS) khususnya dalam tatanan rumah tangga mandi, cuci kakus, personal hygiene serta sanitasi oleh masyarakat merupakan sebuah inisiatif yang dirancang untuk menpromosikan Sanitasi Berbasis Masyarakat (SBM) sebagai pilihan bagi masyarakat miskin perkotaan. Dengan terbatasnya opsi pembuangan limbah yang ada saat ini, Sanimas bertujuan untuk mengenalkan pilihan lain, yaitu sistem pembuangan limbah berbasis masyarakat.

Upaya ini diharapkan bisa menjadi pilihan pemerintah setempat dalam strategi pembangunan sanitasinya upaya untuk menciptakan dan melestarikan perilaku hidup berorientasi kepadan kebersihan dan kesehatan di masyarakat, dapat mandiri dalam mencegah dan menanggulangi masalah-masalah kesehatan yang dihadapinya (Kemnkes RI, 2011). Program SANIMAS dapat membantu kualitas dalam pemenuhan kebutuhan sehari - hari dan menjadikan masyarakat secara mandiri dalam kesehatan dan memberikan inovasi dalam pengolahan limbah dan menjadikan peningkatan secara financial.

Ada tiga model sanitasi berbasis masyarakat menurut Prihandrijanti \& Firdayati (2011) adalah tangki septik komunal untuk 4 hingga 5 rumah tangga yang 
memiliki toilet sendiri akan terhubung dengan saluran ke tangki septik komunal, Penambahan MCK komunal dengan pengolahan biogas, terdapat saluran pembuangan yang mengarah ke fasilitas pengolahan limbah komunal berbentuk baffle reactor (bak penyekat). Pada model ini setiap rumah tangga harus memiliki toilet dan disambungkan ke saluran pembuangan.

Pendapat dari Yeang (2006), sistim sanitasi ekologis yang berfungsi untuk mengolah limbah tinja, limbah hewan dan limbah dapur dengan anaerobic system atau pengolahan secara biologis dengan menggunakan mahluk hidup berupa bakteri sebagai pencerna limbah. Teknologi yang memanfaatkan proses fermentasi dari sampah organik secara anaerobik adalah biogas. Biogas diproduksi didalam alat biodigester oleh fermentasi anaerobik dengan bantuan bakteri methanogenic. Hasil pengolahan limbah manusia dengan biogas dapat dihasilkan antara lain: gas metan untuk bahan bakar generator dan kompor. Endapan lumpur digunakan untuk pupuk pertanian dan air limpasan disaring dengan tanaman air yang dapat menjadi nutrisi pada kolam ikan. Inovasi- inovasi bertujuan memberikan solusi kepada partisipan, yang dapat meningkatkan kualitas kesehatan lingkungan juga dapat mengembangkan produktivitas masyarakat dalam bidang kesehatan maupun finasial secara mandiri .

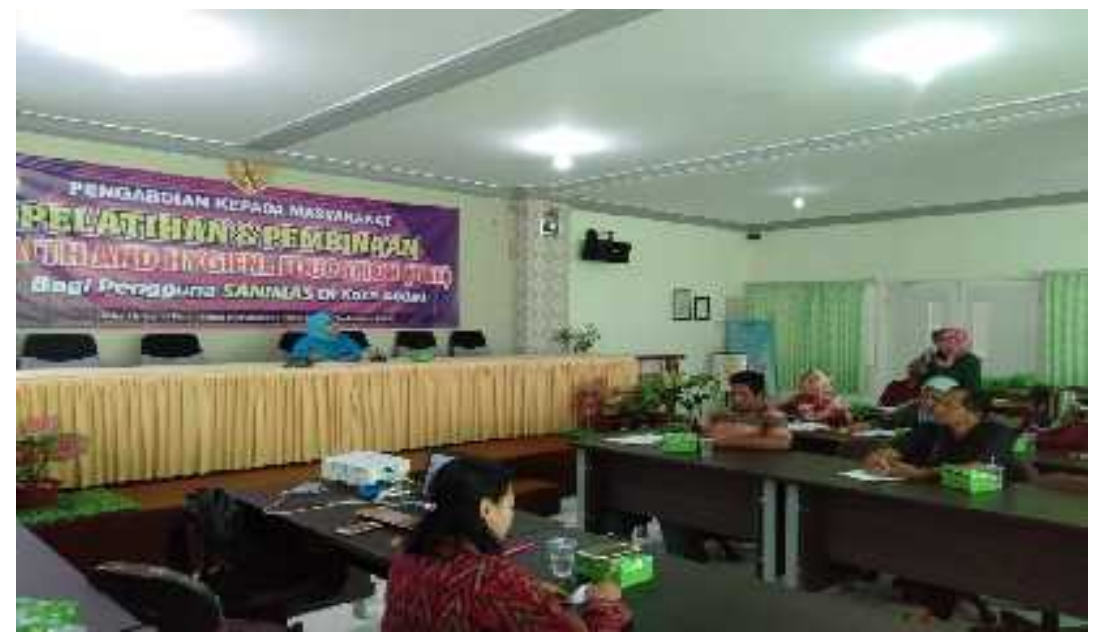

Gambar 4.2.2 Kegiatan Focus Group Discusion dengan partisipan dan narasumber, moderator dari Koordinator SANIMAS Kota Kediri 
Pada kegiatan FGD ini terdapat partisipan yang bertanya tentang mekanisme pengajuan dana untuk perawatan SANIMAS yang sudah mulai rusak untuk infrastrukturnya, dalam diskusi tersebut narasumber memberikan solusi untuk membuat pengajuan surat tertulis untuk ditujukan ke pemerintah kota dan berkerja sama dengan dinas perkerjaan umum.

Hasil dari pengetahuan untuk sebelum dan sesudah kegiatan FGD terdapat pada tabel 4.2.1 dibawah ini :

Tabel 4.2.1 Pengetahuan sebelum dan sesudah pelatihan dan pembinaan sanimas SANIMAS.

\begin{tabular}{lcccc}
\hline & $\begin{array}{c}\text { Pengetahuan sebelum } \\
\text { Pengabdian } \\
\text { Masyarakat }\end{array}$ & $\begin{array}{c}\text { Pengetahuan sesudah Pengabdian } \\
\text { Masyarakat } \\
\text { Kategori }\end{array}$ & $\begin{array}{c}\text { SANIMAS } \\
\text { SANIMAS }\end{array}$ & \\
\cline { 2 - 5 } & Frekuensi & $\%$ & Frekuensi & $\%$ \\
\hline Kurang & 7 & 30.4 & 0 & 0 \\
Cukup & 11 & 47.8 & 2 & 8.7 \\
Baik & 5 & 21.7 & 21 & 91.3 \\
\hline Total & 23 & 100.0 & 23 & 100.0 \\
& & & & \\
\hline
\end{tabular}

Pengetahuan sebelum dan sesudah pelatihan dan pembinaan sanimas terdapat pada tabel 4.2.1 ada perbedaan yaitu untuk sebelum dilakukan Pelatihan dan pembinaan SANIMAS adalah cukup sebanyak 11 partisipan $(47,8 \%)$ dan sesudah dilakukan ada perubahan menjadi baik sebanyak 21 partisipan (91,3\%). Partisipan sebagian besar tidak pernah mengikut pelatihan SANIMAS sebanyak 19 orang (82,6\%). Dukungan dari pemerintah kota Kediri berkerjasam dengan dinas pekerjaan umum sudah $100 \%$ dalam upaya membangun tempat mandi, cuci dan kakus pada masyarakat yang rumahnya dekat dengan sungai.

Faktor-faktor internal yang mempengaruhi bentuk dan tingkat partisipasi masyarakat dalam program SANIMAS faktor jenis pekerjaan, tingkat pendapatan, tingkat pendidikan dan faktor pengetahuan masyarakat. Sedangkan faktor - faktor eksternal yaitu pihak yang berkepentingan terhadap program SANIMAS yang 
mempengaruhi bentuk dan tingkat partisipasi masyarakat adalah pihak pemerintah daerah, pengurus desa, tokoh masyarakat dan fasilitator (Surotinojo, 2009). Peran pemerintah, tokoh masyarakat, fasilitaor SANITASI dan kesadaran masyarakat saling berkisinambungan untuk terciptanya SANIMAS yang sehat, indah, sebagai tempat edukasi.

Tabel 4.2.1 Motivasi sebelum dan sesudah pelatihan dan pembinaan SANIMAS.

\begin{tabular}{ccccc}
\hline & $\begin{array}{c}\text { Motivasi sebelum Pengabdian } \\
\text { Masyarakat } \\
\text { SANIMAS }\end{array}$ & $\begin{array}{c}\text { Motivasi sesudah Pengabdian } \\
\text { Masyarakat } \\
\text { Kategori }\end{array}$ & SANIMAS & \\
\cline { 2 - 5 } & Frekuensi & $\%$ & Frekuensi & $\%$ \\
\hline Kurang & 4 & 17.4 & 0 & 0 \\
Cukup & 11 & 47.8 & 4 & 17.4 \\
Baik & 8 & 34.8 & 19 & 82.6 \\
\hline Total & 23 & 100.0 & 23 & 100.0 \\
\hline
\end{tabular}

Hal ini didukung dari hasil motivasi sebelum dan sesudah pelatihan dan pembinaan SANIMAS, bahwa sebagian besar menujukkan sebagian besar motivasi sebanyak 19 partisipan $(82,6 \%)$. Hal ini menunjukkan ada rasa tanggung jawab dan kesadaran dari partisipan untuk menjadi lebih sehat mandiri, tetapi hal ini memerlukan dukungan dan pendampingan sampai evaluasi dari lintas sektor untuk tercapainya program SANIMAS. Kegiatan ini diakhir dengan kegiatan foto bersama pada gambar 4.2.3 untuk meningkatkan kebersamaan dan program keberlanjutannya.

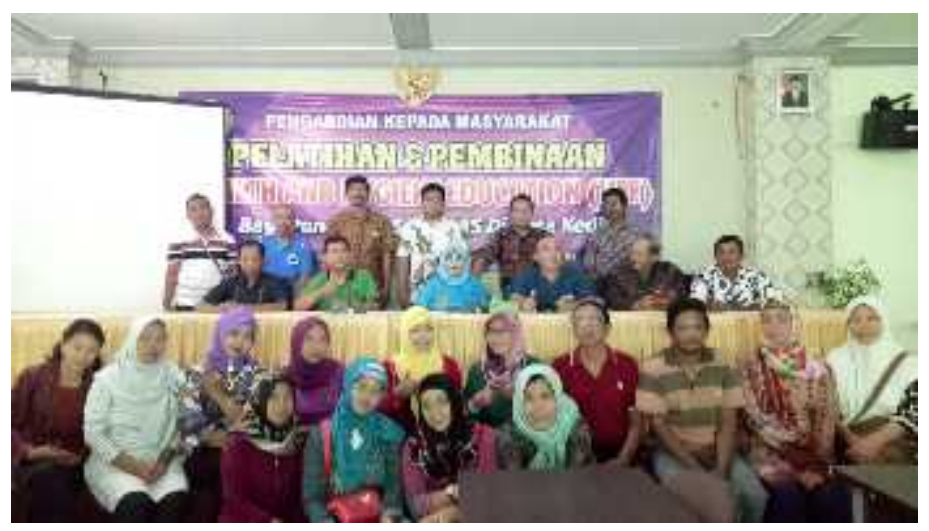

\section{Gambar 4.2.3 Foto Bersama kegiatan dengan narasumber serta partisipan}




\section{DAFTAR PUSTAKA}

AKSANSI, 2016. Hasil Pre-Monitoring Sanimas Kota Kediri

Bappeda Kota Kediri,(2010), Buku Putih Sanitasi Kota Kediri

Bappeda kota Kediri, (2011) Strategi Sanitasi Kota Kediri.

Indrizal, e. (2014) 'diskusi kelompok terarah focus group discussion (fgd) (prinsipprinsip dan langkah pelaksanaan lapangan)', jurnal antropologi: isu-isu sosial budaya, 16(1), pp. 75-82.

Prihandrijanti, Maria dan Firdayati, Mayrina, 2011, Current Situation and Consideration of Domestic Wastewater Treatment Plant for Big Cities in Indonesia (Case Study: Surabaya and Bandung),Jurnal of Water Sustainability, Vol. 1, 2 September 2011, University of Technology Sydney \& Xi'an University Architecture and Technology.

R I, Kemenkes. (2011) Pedoman Pembinaan Perilaku Hidup Bersih dan Sehat (PHBS) (Peraturan Menteri Kesehatan Republik Indonesia nomor: 2269/MENKES/PER/XI/2011). Jakarta.

Surotinojo, I. (2009) partisipasi masyarakat dalam program sanitasi oleh masyarakat ( sanimas ) di desa bajo kecamatan tilamuta. Tesis.Program Studi Magister Teknik Pembangunan Wilayah dan Kota Program Pascasarjana Universitas Diponegoro

Simlitabmas Ristek Dikti. (2016). Pedoman Pengabdian kepada Masyarakat 2016. Jakarta : Kemenristek.

Yeang, Kenneth, 2006, Ecodesign: Design for Water Conservation, Recycling, Harvesting, etc:Conserving Water Resources,John Wiley and Sons, Ltd, London, pp. 262-267. 